\title{
Intussusception as gastrointestinal manifestation in COVID-19 patients in paediatric age group
}

\author{
Lamia Inayath, Taha Daginawala, Natasha Vageriya*, S. B. Mane, Hemangi Athawale
}

Department of Paediatric Surgery, Grant Government Medical College and Sir JJ Group of Hospitals, Mumbai, Maharashtra, India

Received: 01 January 2022

Revised: 30 January 2022

Accepted: 02 February 2022

*Correspondence:

Dr. Natasha Vageriya,

E-mail: natashavageriya@gmail.com

Copyright: () the author(s), publisher and licensee Medip Academy. This is an open-access article distributed under the terms of the Creative Commons Attribution Non-Commercial License, which permits unrestricted non-commercial use, distribution, and reproduction in any medium, provided the original work is properly cited.

\begin{abstract}
As knowledge of the varied manifestations of coronavirus disease 2019 (COVID-19) infection expands, symptoms such as vomiting and diarrhoea are noted as the main gastrointestinal symptoms in these patients, especially paediatric age group. With the predictions of third wave of COVID approaching soon and likely to affect paediatric population, especially in a developing country like ours, it is important to know the various presentations and managements of COVID 19. Intussusception is a common cause of bowel obstruction in the paediatric age group. Preceding viral illness and fever have been established as its underlying cause. In this report, we are reporting 2 cases of COVID 19 infection presenting as intussusception. Till June 2021, only 10 such cases have been reported worldwide.
\end{abstract}

Keywords: COVID-19, SARS-COV-2, Intussusception, Paediatric population

\section{INTRODUCTION}

Coronavirus disease 2019 (COVID 19) infection in children, especially infants is underreported as patients are usually asymptomatic or mildly symptomatic and also, as testing is very less amongst them. ${ }^{1}$ Gastrointestinal manifestations of COVID 19, such as vomiting, nausea, abdominal pain has increasingly been recognized as common manifestations in children. ${ }^{2}$ Chinese and Italian studies have shown that approximately $10 \%$ children present with GI symptoms.

Intussusception is a common cause of small bowel obstruction in the paediatric age group. ${ }^{3,4}$ Highest incidence is noted between 6-12 months during infancy. Preceding viral illness is an established etiology and diurnal variations in the frequency corroborates with the same. Local immune activation and mesenteric adenitis predispose peristaltic activity to "telescope" a proximal bowel segment into the distal bowel lumen. ${ }^{5-8}$ Since the COVID-19 incidence has been rising globally, several considerations are getting validated regarding the disease course in paediatric age group. Some case reports of intussusception as the presenting symptom are noted recently in literature, however they are scarce to construct a factual ground for the association between the two. Adding to it we present 2 cases of infants who presented to us with intussusception and COVID-19 infection.

\section{CASE REPORT}

A 10 months male baby, $9.6 \mathrm{~kg}$, weaned off breast feeds at 6 months of age, had complaints of fever and refusal to feed for 4 days, with passage of blood in stool with mucoid stool intermittently for 2 days and vomiting for 1 day. On examination, the abdomen was soft, non-tender, no palpable lump. Per rectal examination revealed bloodtinged mucoid stools (red currant jelly stools). Patient was admitted and Ryle's tube was inserted, aspirate was bilious. Ultrasonography was done which was suggestive of an ileocolic intussusception up to the hepatic flexure in right lumbar and hypochondriac region. X-ray erect 
abdomen showed dilated small bowel loops, without fluid levels. An RTPCR oropharyngeal swab was sent on admission. Blood investigations revealed a low haemoglobin of $8.4 \mathrm{~g} / \mathrm{dl}$, total leukocyte count- 10,400 and a normal platelet count. Patient was kept nil by mouth and hydrated with IV fluids over 4 hours and started on IV antibiotics (cefotaxime and metronidazole).

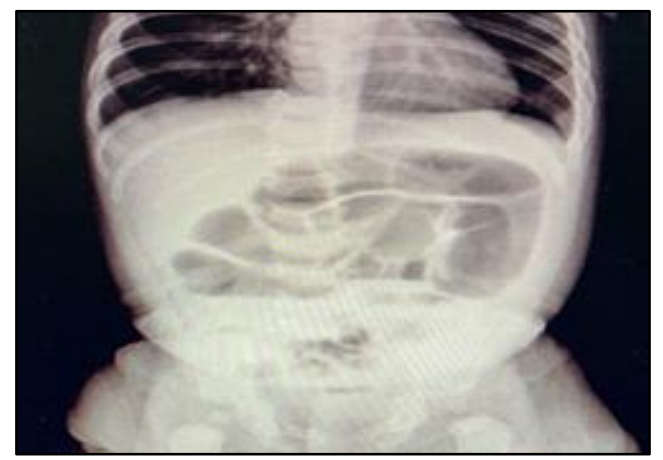

Figure 1: Erect x-ray abdomen.

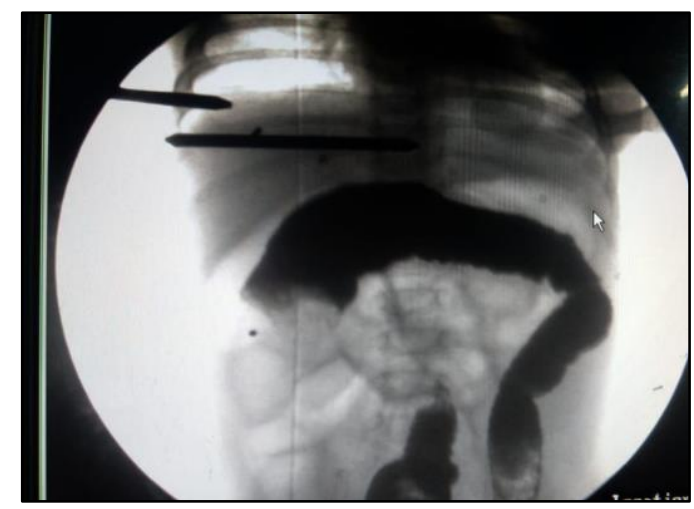

Figure 2: $\mathrm{C}$ arm guided image showing claw sign in hepatic flexure.

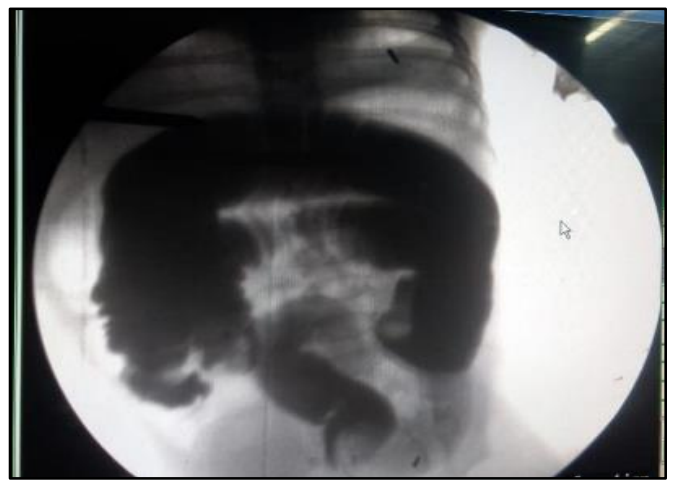

Figure 3: Barium in small bowel following reduction.

Patient was taken up for $\mathrm{C}$ arm guided hydrostatic reduction after adequate hydration. Barium was used as a contrast medium. Claw sign was identified at mid transverse colon, and gradual reduction of intussusception was done using sustained pressure till contrast passed into terminal ileum. Hydration was continued during the procedure. Sedation was achieved with intravenous midazolam and Ryle's tube was kept on continuous drainage. the contrast instilled was evacuated at the end of the procedure accompanied by the passage of stool. After 6 hours of assessment, child was comfortable, abdomen was soft and had passes stool twice (formed, yellow coloured) and RT aspirate was non bilious. Patient was started on liquid diet and tolerated it well after which full feeds were resumed. Fever persisted after reduction and the child tested positive for COVID19 on RT PCR. Patient was started on chloroquine, azithromycin and oseltamivir according to weight. Medications were continued for 5 days. Child was afebrile on the 3rd day post intussusception reduction. A repeat oro-pharyngeal swab was sent on the 5th day post reduction which tested positive for COVID-19 on RT PCR. Child was continued for observation after 5 days of medication and was afebrile. As per change in ICMR guidelines for Covid patients, child was discharged after being afebrile for 10 days (no repeat swab) and home quarantine for 14 days. No medications were given at discharge and dietary counselling was done.

6 months old baby, weight $8 \mathrm{~kg}$, on breastfeeding, presented with complaints of irritability and refusal of feeds for 1 day with passage of red currant jelly stools. On examination, abdomen was soft, lump was palpable in the right hypochondrium. Per rectal examination revealed blood-streaked mucoid stools. Erect X-ray abdomen (Figure 1) showed few airs fluid levels. USG abdomen showed features suggestive of colo-colic intussusception. Patient was admitted and kept NBM and hydrated with IV fluids for 5 hours and started on IV antibiotics (cefotaxime and metrogyl). After adequate hydration, patient was taken up for $\mathrm{C}$ arm guided hydrostatic reduction. Claw sign was noted in the hepatic flexure (Figure 2) and gradual reduction of intussusception was done under sustained pressure until contrast was seen in the ileum (Figure 3). Hydration was continued during the procedure and contrast was evacuated at the end of the procedure. Six hours post procedure, patient was comfortable, abdomen was soft and patient had passed stools once, which was yellow in colour and normal in consistency. Patient had undergone a nasopharyngeal swab at the time of admission according to hospital protocol which was found to be positive. Patient was transferred to COVID hospital as per hospital protocol for further management. Patient was kept at COVID hospital for a week and given medications and swab repeated tested negative and patient was discharged subsequently.

Both these patients are on follow up and are doing well, with negative COVID RTPCR reports.

\section{DISCUSSION}

COVID 19 is caused by the novel 2019 coronavirus strain SARS-CoV-2, that emerged in late 2019 and has been subsequently declared a global pandemic by the World Health Organization (WHO) on March 2, 2020. ${ }^{1-3}$ 
Table 1: Overview of reported cases of intussusception and SARS COV-2 infection worldwide (till June 2021).

\begin{tabular}{|c|c|c|c|c|c|c|c|c|c|c|c|c|}
\hline Presentation & $\begin{array}{l}\text { Cai et al, } \\
\text { Wuhan, } \\
\text { China }\end{array}$ & $\begin{array}{l}\text { Rajalaks } \\
\text { hmi et } \\
\text { al,Chenn } \\
\text { ai, India }\end{array}$ & $\begin{array}{l}\text { Moazzam et } \\
\text { al, Karachi, } \\
\text { Pakistan }\end{array}$ & $\begin{array}{l}\text { Martinez- } \\
\text { Castanoet } \\
\text { al, } \\
\text { Espana }\end{array}$ & $\begin{array}{l}\text { Makrinioti et } \\
\text { al, Londres, } \\
\text { UK }\end{array}$ & $\begin{array}{l}\text { Buzuave- } \\
\text { Ekwuvasi et } \\
\text { al, } \\
\text { Galveston, } \\
\text { USA }\end{array}$ & $\begin{array}{l}\text { Mercado } \\
\text { et al, } \\
\text { Saltillo, } \\
\text { Mexico 1 }\end{array}$ & $\begin{array}{l}\text { Mercado et } \\
\text { al, Saltillo, } \\
\text { Mexico } 2\end{array}$ & $\begin{array}{l}\text { Jackson } \\
\text { et al, New } \\
\text { York, } \\
\text { USA }\end{array}$ & $\begin{array}{l}\text { Athamna } \\
\text { h et al }\end{array}$ & $\begin{array}{l}\text { Our } \\
\text { study } 1 \\
\text { Mumbai, } \\
\text { India }\end{array}$ & $\begin{array}{l}\text { Our study } \\
2 \\
\text { Mumbai, } \\
\text { India }\end{array}$ \\
\hline Age & 10 months & 8 months & 4 months & 6 months & 10 months & 9 months & 8 months & 7 months & 25 years & $\begin{array}{l}2 \text { and } 1 / 2 \\
\text { months }\end{array}$ & 10 months & 6 months \\
\hline $\begin{array}{l}\text { Symptom } \\
\text { evolution }\end{array}$ & $\begin{array}{l}\text { Initially } \\
\text { intussuscepti } \\
\text { on } \\
\text { symptoms, } \\
\text { then SARS } \\
\text { CoV- } 2 \\
\text { positive test }\end{array}$ & $\begin{array}{l}\text { Initially } \\
\text { intussusce } \\
\text { ption } \\
\text { symptoms, } \\
\text { then } \\
\text { SARS } \\
\text { CoV-2 } \\
\text { positive } \\
\text { test }\end{array}$ & $\begin{array}{l}\text { Initially } \\
\text { intussusception } \\
\text { symptoms, then } \\
\text { SARS CoV- } 2 \\
\text { positive test }\end{array}$ & $\begin{array}{l}\text { Initially } \\
\text { intussusce } \\
\text { ption } \\
\text { symptoms, } \\
\text { then SARS } \\
\text { CoV-2 } \\
\text { positive } \\
\text { test }\end{array}$ & $\begin{array}{l}\text { Initially SARS } \\
\text { CoV-2 positive } \\
\text { test hen } \\
\text { intussusception } \\
\text { symptoms }\end{array}$ & $\begin{array}{l}\text { Initially } \\
\text { SARS CoV- } \\
2 \text { positive } \\
\text { test hen } \\
\text { intussuscepti } \\
\text { on } \\
\text { symptoms }\end{array}$ & $\begin{array}{l}\text { Initially } \\
\text { SARS } \\
\text { CoV-2 } \\
\text { positive } \\
\text { test hen } \\
\text { intussusce } \\
\text { ption } \\
\text { symptoms }\end{array}$ & $\begin{array}{l}\text { Initially } \\
\text { intussuscepti } \\
\text { on } \\
\text { symptoms, } \\
\text { then SARS } \\
\text { CoV- } 2 \\
\text { positive test }\end{array}$ & $\begin{array}{l}\text { Initially } \\
\text { SARS } \\
\text { CoV-2 } \\
\text { positive } \\
\text { test hen } \\
\text { intussusce } \\
\text { ption } \\
\text { symptoms }\end{array}$ & $\begin{array}{l}\text { Initially } \\
\text { intussusce } \\
\text { ption } \\
\text { symptoms } \\
\text {, then } \\
\text { SARS } \\
\text { CoV- } 2 \\
\text { positive } \\
\text { test }\end{array}$ & $\begin{array}{l}\text { Initially } \\
\text { intussusce } \\
\text { ption } \\
\text { symptoms } \\
\text {, then } \\
\text { SARS } \\
\text { CoV-2 } \\
\text { positive } \\
\text { test }\end{array}$ & $\begin{array}{l}\text { Initially } \\
\text { intussuscep } \\
\text { tion } \\
\text { symptoms, } \\
\text { then SARS } \\
\text { CoV-2 } \\
\text { positive test }\end{array}$ \\
\hline Fever & $\begin{array}{l}\text { Detected } \\
\text { upon arrival } \\
\text { to the } \\
\text { hospital }\end{array}$ & $\begin{array}{l}2 \text { days } \\
\text { before }\end{array}$ & No & No & 2 weeks before & 1 day before & $\begin{array}{l}2 \text { days } \\
\text { before }\end{array}$ & $\begin{array}{l}\text { Detected } \\
\text { upon arrival } \\
\text { to the } \\
\text { hospital }\end{array}$ & $\begin{array}{l}1 \text { week } \\
\text { prior }\end{array}$ & $\begin{array}{l}10 \text { days } \\
\text { prior }\end{array}$ & $\begin{array}{l}4 \text { days } \\
\text { before }\end{array}$ & No \\
\hline $\begin{array}{l}\text { Respiratory } \\
\text { symptoms }\end{array}$ & No & No & 1 week before & No & 2 weeks before & $\begin{array}{l}4 \text { days } \\
\text { before }\end{array}$ & No & $\begin{array}{l}1 \text { week } \\
\text { before }\end{array}$ & $\begin{array}{l}1 \text { week } \\
\text { before }\end{array}$ & $\begin{array}{l}10 \text { days } \\
\text { prior }\end{array}$ & No & No \\
\hline $\begin{array}{l}\text { Type of } \\
\text { intussusce } \\
\text { ption }\end{array}$ & $\begin{array}{l}\text { Not } \\
\text { specified }\end{array}$ & Ileocolic & Ileocolic & $\begin{array}{l}\text { Ileocaeca } \\
1\end{array}$ & Not specified & Ileocolic & Ileocolic & Ileocolic & Ileocolic & Ileocolic & Ileocolic & Colo-colic \\
\hline $\begin{array}{l}\text { Treatment } \\
\text { given }\end{array}$ & Air enema & $\begin{array}{l}\text { Air } \\
\text { enema }\end{array}$ & Air enema & $\begin{array}{l}\text { Hydrostat } \\
\text { ic enema }\end{array}$ & $\begin{array}{l}\text { Failed air } \\
\text { enema, surgical } \\
\text { reduction+ } \\
\text { Ladds procedure }\end{array}$ & $\begin{array}{l}\text { Hydrostatic } \\
\text { enema }\end{array}$ & $\begin{array}{l}\text { Surgical } \\
\text { reduction }\end{array}$ & $\begin{array}{l}\text { Surgical } \\
\text { reduction }\end{array}$ & $\begin{array}{l}\text { Right } \\
\text { hemicolec } \\
\text { tomy }\end{array}$ & Air enema & $\begin{array}{l}\text { Hydrostatic } \\
\text { reduction }\end{array}$ & $\begin{array}{l}\text { Hydrostatic } \\
\text { reduction }\end{array}$ \\
\hline Outcome & Death & Recovered & Recovered & Recovered & Recovered & Recovered & Recovered & Recovered & Recovered & Recovered & Recovered & Recovered \\
\hline
\end{tabular}


As of July 2021, the number of covid cases in India are around 3 crores with around 4 lakh deaths. ${ }^{4}$

Asper the data from the Indian council of medical research (ICMR) on the Dash board of National centre for Disease control, $11.89 \%$ of covid 19 cases in India are under the age group of children and adolescents, as compared to the USA where it has been reported that $13 \%$ of all cases of COVID 19 were among children. ${ }^{5,6}$ Intussusception is one of the commonest abdominal emergencies in children between 3 months to 3 years. ${ }^{7,8}$ Viral infections are the most common etiological factors in intussusception. Although the pathogenesis of intussusception related to the SARS-CoV-2 is not fully understood, it can be inferred that it involves alteration in peristaltic intestinal movement that allows intussusception. ${ }^{2}$ SARS-CoV-2 RNA has been identified in anal/ rectal swabs and stool specimens even after the clearance of the virus in the upper respiratory tract. These corroborate the GI involvement in COVID-19. ${ }^{9,10}$

Once infected by SARS-CoV-2, the gastrointestinal epithelium has an increased permeability to pathogens in response to which Peyer's patches in the ileum undergo hypertrophy and cause mucosal prolapse favoring a lead point of intussusception. ${ }^{3}$ Angiotensin-converting enzyme 2 (ACE2) receptor is the functional receptor for SARSCoV-2. ${ }^{4,11}$

The gold standard treatment for intussusception is nonsurgical reduction of intussusception by hydrostatic or pneumatic reduction. ${ }^{5,12,13,15}$ In our report, both cases were reduced by hydrostatic reduction and both patients recovered completely post procedure without any surgical intervention. Hence, it is favorable to treat COVID 19 elated intussusception by non-surgical reduction.

On review of English literature on COVID 19 with intussusception till date, we have found only 10 cases reported worldwide, 9 in children, ages ranging from 4-9 months, and 1 in adult, aged 25 years. Of the 9 paediatric patients, only 3 required surgical reduction and 6 recovered completely post hydrostatic or pneumatic image guided reduction. Only 1 death was reported, as in the first reported case from Wuhan, China. ${ }^{10}$ With the prediction of third wave approaching soon and it being likely to affect the paediatric population more, it is important for health professional to be vigilant in diagnosing COVID 19 patients with surgical abdominal conditions without creating a situation of panic. As seen by the analysis in Table 1, it is evident that patients with COVID 19 related intussusception can be managed with image guided non-surgical reduction and surgical reduction if required Majority of these patients are doing well on follow up post COVID 19 recoveries.

\section{CONCLUSION}

With the rise of COVID in children with the second wave in India, it has become more important to diagnosis covid in paediatric patients early to prevent morbidity and mortality. With the contribution of more cases to both disease, future research may help to provide further information to understand if intussusception is a manifestation of COVID 19 or whether it is a complication of the disease. With this report, it may also be concluded that patients presenting with COVID 19 intussusception may be completely managed with nonsurgical reduction alone.

\section{Funding: No funding sources \\ Conflict of interest: None declared \\ Ethical approval: Not required}

\section{REFERENCES}

1. Moazzam Z, Salim A, Ashraf A, Jehan F, Arshad M. Intussusception in an infant as a manifestation of COVID-19. J Pediatr Surg Case Rep. 2020;59:101533-3.

2. Martinez I, Gutierrez F, Pena A. Intussusception and SARS-CoV 2 infection. J Paed Surg Case Rep. 2021;67:101808-8.

3. Giovanni J, Hrapcak S, Melgar M, Godfred-Cato S. Global Reports of Intussusception in Infants With SARS-CoV-2 Infection. The Pediatric Infectious Disease Journal. 2021;40:1.

4. McGowan RJ. Coronavirus disease 2019 (COVID 19) in children, June 2021, medscape Available at: https://emedicine.medscape.com/article/2500132overview. Accessed on 10 December 2021.

5. Bazuaye-Ekwuyasi A, Camacho A, Rios F, Torck A, Choi W, Aigbivbalu E, et al. Intussusception in a child with COVID-19 in the USA, 2020. Emergency Radiology. 2020;27:761-4.

6. Makrinioti H, MacDonald A, Lu X, Wallace S, Jobson M, Zhang F, et al. Intussusception in 2 Children With Severe Acute Respiratory Syndrome Coronavirus-2 Infection. JPIDS. 2020;9.

7. Rajalakshmi L, Satish S, Nandhini G, Ezhilarasi S. Unusual presentation of covid-19 as intussusception. Indian Journal of Paedatrics. 2020;22(2):236-8.

8. Athamnah M, Masade S, Hamdallah H, Banikhaled N, Shatnawi W, Elmughrabi M, et al. COVID 19 presenting as intussusception in infants: a case report with literature review, J Pediatr Surg Case Rep. 2021;66:101779.

9. Akhila KP, John J. The Impact Of COVID-19 On Children And Adolescents: An Indian perspectives And Reminiscent Model, International Journal of Aquatic Science ISSN: 2008-8019 Vol 12, Issue 02, 2021. Available https://search.bvsalud.org/global-literature-onnovel-coronavirus-2019ncov/resource/en/covidwho-1326249. Accessed on 24 December 2021.

10. Jackson K, Sabbota A. Right hemicolectomy for ileocolic intussusception in an adult with active COVID 19 infection: a case report, J Surg Case Rep. 2021;(6):rjab205. 
11. Zhang T, Cui X, Zhao X, Wang J, Zheng J, Zheng $\mathrm{G}$, et al. Detectable SARS-CoV-2 viral RNA in feces of three children during recovery period of COVID-19 pneumonia. J Med Virol. 2020.

12. Selvaraj G, Kirkwood C, Bines J, Buttery J. Molecular epidemiology of adenovirus isolates from patients diagnosed with intussusception in Melbourne, Australia. J Clin Microbiol. 2006;44:3371-3.

13. Hamming I, Timens W, Bulthuis ML, Lely A, Navis $\mathrm{G}$, Goor H. Tissue distribution of ACE2 protein, the functional receptor for SARS coronavirus. A first step in understanding SARS pathogenesis. J Pathol. 2004;203:631-7.

14. Osorno J, Giraldo M, Marin A, Figueroa L. Novel Coronavirus Infection in an Infant with Intussusception, Surgery-Case Report. Global Pediatric Health. 2020;8:1-3.

Cite this article as: Inayath L, Daginawala T, Vageriya N, Mane SB, Athawale H. Intussusception as gastrointestinal manifestation in COVID-19 patients in paediatric age group. Int J Contemp Pediatr 2022;9:303-7. 